\title{
The Legal Liability of the Public Assessment Office (KJPP) on the Assessment Result of Banking Credit Collateral (Study at PT. Bank Bukopin, Tbk. Branch Solo)
}

\author{
Heri Siswanto $^{1 *}$, Pujiyono $^{2}$, Yudho Taruno Muryanto ${ }^{3}$ \\ ${ }^{1}$ Mahasiswa Pascasarjana Program Ilmu Hukum Universitas Sebelas Maret, Jalan 36 Kentingan, Jebres, Surakarta, Jawa Tengah, Indonesia \\ ${ }^{2,3}$ Dosen Fakultas Hukum Universitas Sebelas Maret Jalan 36 Kentingan, Jebres, Surakarta, Jawa Tengah, Indonesia
}

*Corresponding author: Hari Siswanto

\section{Abstract}

Providing funds for consumers by a finance company (bank) to buy consumer goods whose payments are made by the installments or conducted periodically by consumers called as financing or consumer credit. The responsibilities of the public appraisal service in the appraisal agreement with the service user, it is stated that the appraisal service company responsibility is only limited due to the time and place of the implementation of assessment, where the appraisal service company is responsible for assets and reports other than those that occur after time and the place stated in the report is no longer the responsibility of the appraisal service company after conducting an appraisal and issuing the report. The legal material analysis technique was conducted by using grammatical and systematic interpretation. The results obtained in this study indicated that there is a repressive legal protection that can be provided to banks as a disadvantaged party due to a default of public appraisers in the appraisal report. The protection is in the form of completing a civil suit on the basis of tort or civil suit on the basis of acts against the law. In addition, banks can also propose a criminal suits on the basis of fraud. The need for special arrangements regarding the appraisal agreement and accountability of public appraisers, in order to prevent things that can harm the parties concerned and maintain the reputation of the public appraiser as a professional service.

Keywords: Appraisal, Act against the law, Credit.

Copyright @ 2020: This is an open-access article distributed under the terms of the Creative Commons Attribution license which permits unrestricted use, distribution, and reproduction in any medium for non-commercial use (NonCommercial, or CC-BY-NC) provided the original author and source are credited.

\section{INTRODUCTION}

Nowadays, the asset/ property valuation or appraisal is urgently required by both the private sector and the government, both central and regional, to increase the accountability and create an orderly administration to encourage asset management (optimization) in a better and more modern way. Property valuation can be used for many things, for example: Property valuation for the purpose of buying and selling, rental eligibility and assessment of current leases and to assess tax objects to determine tax targets, assess regional assets for the purposes of preparing regional balance/ financial statements and to calculate the composition of debt and equity in the capital structure of a business.

Appraisal services can be used for general purposes, however, these days, they are used more by the business world and government agencies. The purpose and reason for evaluating assets, in essence, includes the following matters:

1. Complete the loan application

2. The development and rehabilitation of companies with investment facilities from the Government.

3. Companies that will go public (initial public offering/ IPO).

4. Insurance closure.

5. Company mergers/ acquisitions.

6. Transfer of rights.

7. Company liquidation.

8. Stipulation of NJOP on Land and Building Tax (PBB)

Law of the Republic of Indonesia Number 10 of 1998 concerning Amendment to Law Number 7 of 1992 concerning Banking (hereinafter referred to as the Banking Act) in Article 1 Paragraph 2 "The bank acts as an intermediary institution (channeling the need for funds from the owner to the borrower". 
In carrying out this role the bank is in constant contact with its customers. Article 1 number 16 of the Banking Act itself divides the understanding of the customer into two namely depositing customers and debtor customers. Depositing customers are customers who place their funds in a bank in the form of deposits based on a bank agreement with the customer concerned, whereas a debtor customer is a customer who obtains a credit or financing facility based on sharia principles or the equivalent is based on a bank agreement with the customer concerned.

Article 1 point 11 of the Banking Law, states that "Credit is the provision of money or bills which can be equaled, based on a loan agreement between the bank and another party that requires the borrower to repay the debt after a certain period of time with interest". Credit given by banks is based on trust so that giving credit is giving trust to customers.

To obtain this confidence before giving credit, banks must conduct a careful assessment of the character, capital capability, collateral and business prospects of the debtor. In the context of safeguarding credit disbursement, banks generally require a guarantee in providing credit facilities. Since each credit channel contains risks, collateral is a necessity in banking activities. Collateral according to the Banking Act is a belief in good faith and the ability and ability of debtor customers to repay their debts or return the intended financing in accordance with the agreement between the debtor and creditor.

Collateral has a very important role in providing credit, especially for banks as creditors so that the credit value is commensurate with the value of the collateral so that there is no over credit. Banks often use the Public Appraisal Service Office, hereinafter referred to as (KJPP), to assist in evaluating collateral from prospective debtors because the Public Appraiser is considered to be truly capable in the field of valuation and will provide an objective and credible valuation result. By using the public appraisal service, it is expected that collateral valuation is not wrong and there is no over-engineering of collateral value $\left[{ }^{1}\right]$.

Definition KJPP is a business entity that has obtained a business permit from the minister as a forum for public appraisers to provide their services. KJPP is a business entity/ civil partnership that engages in the field of evaluation services including but not limited to assets/ business feasibility, projects, or guarantees of prospective borrowers who apply for credit facilities to the Bank. In essence, an appraisal service business is a

${ }^{1}$ Njo Anastasia, Penilaian Agunan Kredit Berstatus Surat Hijau, Jurnal Manajemen dan Kewirausahaan, Vol. 8, No.2, September 2006, h.117 business entity that has the title as a trust institution for parties conducting trade transactions $\left[{ }^{2}\right]$.

The role of the appraisal company becomes meaningful because this institution is a professional service business to provide objective and independent valuations for tangible and intangible properties. Therefore, the presence of this institution is very beneficial for economic actors. The appraisal profession began to be recognized in Indonesia around 1970, which was at the same time as investment activities in Indonesia warmed up as a follow up to the implementation of Law Number 8 of 1995 concerning Foreign Investment and Law Number 6 of 1968 concerning Domestic Investment. Appraisal service business is a professional service business to provide an objective and independent valuation of assets or property.

In general, KJPP is regulated in Minister of Finance Regulation Number 101/ PMK.01/ 2014 concerning Public Appraisers. In the 2014 PMK 101, the evaluation activities carried out by KJPP generally included land, building, land development, shopping, office, hospitality, apartment, industrial, mining and plantation activities. Judging from the appraisal activities carried out by appraisal service companies, one of them is property valuation that can be used by banks to assess an object that will be used as a credit guarantee. The bank uses the valuation report as a basis for granting credit, and the basis for calculating it for sale if it has to be auctioned, as well as for calculating the wealth of the bank or customer.

In its operational activities, banks sometimes experience bad credit, however sometimes when executing collateral to pay off debtors' obligations, it turns out the collateral sales results are not as expected and not enough to cover debtor bills. In relation to the purpose of granting credit and the use of KJPP, it is necessary to examine whether the results of the collateral appraisal by the Public Appraiser are binding and must be obeyed by the bank or only constitute nonbinding considerations for banks in determining the appropriate collateral value and credit value. Furthermore, it is also necessary to understand the Public Appraiser's accountability if the results of the valuation are detrimental to the bank. With an understanding of these two things, it is expected that the purpose of credit to improve the lives of many people while at the same time bringing in profits for banks can be well implemented.

Bank Bukopin Tbk Limited Company Solo Branch is one of the business units in the same class as the Main Branch Office (KCU). Where this office carries out banking functions as mandated in the Banking Law, which is to collect Third Party Funds

${ }^{2}$ Njo Anastasia, Op.cit., h.118. 
(DPK) and distribute credit needs to the people of Solo Raya and other banking transaction services. PT. Bank Bukopin, Tbk Solo Branch (hereinafter referred to as Bank Bukopin Solo) in charge of 7 Sub-Branch Offices located in the Solo Raya area.

In terms of lending, Bank Bukopin Solo also cooperates with KJPP. For collateral worth more than Rp. 5,000,000,000.00 banks are required to conduct an assessment using an independent appraiser (KJPP). In terms of determining KJPP, Bank Bukopin Solo cannot determine arbitrarily, KJPP that can be used is KJPP who already has a cooperation agreement with PT. Bank Bukopin, Tbk Head Office especially the Legal and Investigation Division in terms of credit collateral valuation. The purpose of the collaboration with KJPP is in order to provide fast and appropriate services in processing credit granting by banks to debtors.

The cooperation agreement is very useful, where banks can find out how the KJPP's reputation is and from the legal side it is expected that the bank and KJPP are equally protected because of the cooperation. KJPP has the duty to provide an assessment/ evaluation of the value of compensation for land/ buildings pledged as collateral to the bank in an objective manner without prejudice to both parties. They work using the norms and the applicable code of ethics (KEPI/ Indonesian Appraiser Code of Ethics and SPI/ Indonesian Appraiser Standards).

The agreements that have been formed are outlined in the form of a cooperation agreement in this case closely related to the rights and obligations of KJPP and the bank, so that legal certainty will be created. Ideally, any interpretation does not required in a contract or agreement, however, clauses, sentences or words in the contract should already be able to automatically explain the purpose of the existing clauses.

\section{Problem Statement}

How is the legal liability of the Public Appraisal Service Office (KJPP) on the results of the assessment of the bank credit collateral?

\section{DISCUSSION}

The part that is in direct contact with the Office of the Public Appraisal Service is a part of banking operations, in which there is an appraisal, risk management and financing operations section and other parts that support the bank's financing business. In addition to the operational part, the business part also plays an important role, where the part is in direct contact with the customer and uses the Value delivered by the Public Appraiser as the basis for approval in principle of financing and determination of the credit or financing ceiling.
Hendrysah (Head of the Legal and Credit Investigation Division of PT. Bank Bukopin, Tbk) stated that. "If the assessment results presented or based on an evaluation of a report from KJPP there is an error that has the potential to cause harm to the bank, then the bank must conduct an evaluation of the collaboration with the relevant KJPP" [3].

Based on the results of research on public appraisal service responsibilities in the appraisal agreement with the service user, it was disclosed that the appraisal service company's responsibility is limited to the time and place of the valuation, where after conducting the appraisal and has issued a report, the appraisal service company's responsibility for assets and reports other than what happens after the time and place listed in the report is no longer the responsibility of the appraisal service company. Matters that occur after appraisal by public appraisal services are no longer the responsibility of appraisers and appraisers can only be accounted for on the results of appraisal at the time, place, object as contained in the appraisal report made by the appraisal service company $\left[{ }^{4}\right]$.

As a profession, Public Appraisers must of course have a standard that must be met so that the assessment process carried out can produce the best possible output and must also be met to maintain the credibility of the profession itself. Related to the Public Appraiser Profession (which in this case must be in the form of KJPP) in carrying out its appraisal activities must be guided by "Indonesian Appraisal Standards". This is expressly determined in article 1 number 3 of the Minister of Finance Regulation concerning Public Appraiser Services.

The Indonesian Appraiser Standard (SPI) and the Indonesian Appraiser Ethics Code (KEPI) were prepared and established by the Indonesian Appraisal Professional Society (MAPPI) as the only Professional Association recognized by the government. MAPPI has been appointed as the only Professional Association so in the future, there will be no room for other associations who want to regulate this profession. This is very important, so there are no internal problems which ultimately interfere with the implementation of the duties of the appraisal profession, as we have seen in other professions, namely Advocates whose parent organizations are not directly appointed by the regulations so that there are many organizations that feel authorized to regulate, and instead hampering the

\footnotetext{
${ }^{3}$ Hendrisyah, “Wawancara dengan Kepala Divisi Legal dan Investigasi Kredit”, pada tanggal 06 November 2019, di Kantor Pusat PT. Bank Bukopin, Tbk di Jakarta.

${ }^{4}$ Joni Emirzon, Aspek-aspek Hukum Perusahaan Jasa Penilai (Appraisal Company), Gramedia Pusaka Utama, Jakarta, 2000,. h. 3.
} 
progress of the profession. Observing the Regulation of the Minister of Finance regarding Public Appraiser Services and also the Indonesian Appraiser Ethics Code (KEPI) and the Indonesian Appraisal Standards (SPI), it is seen the importance of complying with KEPI and SPI for Public Appraisers in carrying out professional duties. KEPI and SPI become mandatory guidelines for Public Appraisers so that the assessment report becomes clear, not misleading and reveals all important matters.

Related to the compliance of KEPI and SPI by the Public Appraiser, whether or not the two matters are stated in the agreement between the appraiser and the assignor is not a problem and will remain legally binding because it has been determined by applicable regulations. But in practice the existence of KEPI and SPI is always set forth in the agreement. Public Appraisers must comply with KEPI and SPI while conducting their profession.

In carrying out the position, Apraissal has a moral responsibility to his profession. According to Paul F. Camanisch as quoted by K. Bertens stated that the profession is a moral community (moral community) that has shared ideals and values. Professional groups have their own powers and special responsibilities. As a profession, this group has a reference called the Professional Code of Ethics. The Code of Ethics is factually the norms or provisions, which are set and accepted by all members of the professional group.

Regarding KJPP's responsibility which in this case acts as appraisal is divided into several forms. The first liability is civil liability, the second is criminal liability liability, and the last is administrative liability. Civil liability usually takes the form of compensation to the injured party. Criminal liability is usually in the form of criminal penalties, whereas administrative liability is usually in the form of warnings, suspension of company licenses, and the most difficult is revocation of company licenses.

Bank Bukopin Solo Branch and KJPP are bound in a cooperation agreement in which there are obligations and rights of each party. If the KJPP does not carry out its obligations in accordance with the provisions contained in the cooperation agreement, the Bank Bukopin Solo Branch can hold the KJPP accountable. This is in accordance with the Cooperation Agreement which contains the rights and obligations of each party so that if there is an act or action that is not in accordance with the agreement, then the accountability can be held.

In accordance with article 47 of PMK 101 of 2014, KJPP is responsible for all services provided. There are three forms of accountability here, namely civil, criminal and administrative. Everything can be charged to the KJPP, depending on the form of violations that have been committed by KJPP. Unfortunately the regulation only regulates administrative requirements along with administrative sanctions.

The sanctions will be determined further by a decision of the Minister of Finance. Administrative sanctions are not always given sequentially. The head of the head office can provide a letter of recommendation to the Public Appraiser, KJPP and / or the KJPP Branch to carry out certain obligations before the imposition of administrative sanctions, so that when these obligations are fulfilled administrative sanctions do not need to be given again.

According to Rizki Novarianto in his interview with the researcher, that administrative sanctions in the form of license revocation are very hard sanctions for KJPP, therefore every KJPP will make every effort to be able to resolve existing problems with third parties if these sanctions will be imposed. He further stated that if this cannot be avoided then this sanction is similar to bankruptcy in a company, where the KJPP cannot operate and the people inside it (KJPP assessors and administrators) will be subject to considerable moral burdens.

Whereas, as can be seen in reality that the increasing number of violations committed by public appraisers can materially harm service users, the valuation agreements, Permenkeu, SPI, KEPI are considered to be inadequate to overcome existing problems. This is because SPI and KEPI do not yet have a strong legal foundation and are no more than a guideline that must be obeyed without legal sanctions both criminal and civil.

The bank, according to the researcher, can use repressive legal protection so that the bank as a party harmed because of the default of public appraisers in the granting of an appraisal report can file civil compensation. The protection is in the form of filing a civil suit on the basis of default or civil suit on the basis of acts against the law. In addition, banks can also file criminal suits on the basis of fraud. However, in the event that an agreement has been made and implemented, then the claim based on fraud cannot be submitted since there is a fundamental difference between the criminal lawsuit and the default lawsuit.

\section{CONCLUSION}

The protection is in the form of filing a civil suit on the basis of default or civil suit on the basis of acts against the law. In addition, banks can also file criminal suits on the basis of fraud. However, if an agreement has been made and implemented, then the lawsuit based on fraud cannot be filed. This happens since there is a different concept between tort and fraud. Then finally, the bank can file a complaint with MAPPI 
for alleged violations committed by the public appraiser in carrying out their duties that are not in accordance with SPI and KEPI. The need for special arrangements regarding the appraisal agreement and accountability of public appraisers, in order to prevent things that can harm the parties concerned and maintain the good name of the public appraiser as a professional service. 